\title{
Detection of Campylobacter spp. in children diarrhea by using Polymerase Chain Reaction PCR technique in Al- Diwanyiah Governorate.
}

\author{
A. H. AL-Hamadani
}

Coll. of Med./Unive. of Al-Qadisiya
Z.F.Saleh

Coll. of Vet. Med./Unive. of Al-Qadisiya

\section{Abstract}

This study was conducted in order to identify of Campylobacter spp. As a causative agent of diarrhea in children using routine laboratory diagnosis (direct and culture methods) in comparison with polymerase chain reaction (PCR) technique as a confirm diagnostic tool.A total of 100 children stool samples were collected from both sexes at ages less than two years olds suffering from diarrhea who admitted the maternity and Pediatric Teaching hospital in Al-Diwaniyiah Governorate from December 2007 to August 2008.Based on the clinical and laboratory diagnosis, results revealed that the percent of Campylobacter isolation was $8 \%$ included $C$. coli and $C$. jejuni for children samples. In addition, the results haven't revealed any statistically significant $(\mathrm{P} \geq 0.01)$ between the rate of infection and sexes, while there was a statistically significant $(\mathrm{P} \leq 0.01)$ between these rates and ages, where it noted that patients (>1) years old were more prone to infect with Campylobacter spp. exposure to infections. The results revealed that the PCR positive samples contained one band of amplified DNA with molecular weight (816 bp) after electrophoresis and examined under UV- transilluminator. The study also showed that the sensitivity and specificity of PCR technique were $40 \%$ and $100 \%$ respectively for examination children samples, when compared with direct examination, but were with culture method were $33 \%$ and $100 \%$; respectively in children.

\section{Introduction}

The thermophilic species of Campylobacter are one of the most important bacterial causes of acute diarrhea disease in human. Studies by the world health organization (WHO) have included them among emerging foodboring pathogens, infect, their incidence in European countries almost doubled between 1985 and 1998. Campylobacter species are carried in the intestinal tracts of a wide variety of wild and domesticated animals (1). Although C.jejuni is a major etiological agent of human enteritis other Campylobacter species, such as $C$. fetus subsp. fetus (2), C. hyointestinelis (3) and C. upsaliensis (4) have been implicated as minor causes of human gastroenteritis. The Epidemiological studies of Campylobacter demonstrated that the ingestion of contamination water or food, or directed contact with infected animals is the most important sources of human infection (5).In microbiology, DNA amplification using polymerase chain reaction (PCR) has allowed great progress to be made in the rapid and accurate diagnosis of infection due to organisms that and are not cultivable by in vitro means, that require selective media and have 1-6 day incubation times or for which culture is too in sensitivity (6). One of first studies on application of PCR, the diagnosis of Campylobacterosis from stool samples was done with amplification target of 816 base pairs (bp). The data of PCR yielded few false positive and was impressive in its ability to distinguish Campylobacter spp. from embryonic fluid of abortion embryonic (7). As alternative, molecular amplification techniques can provide highly sensitive and specific method for the detection identification and characterization of fecal samples including Campylobacter spp. and numbers of PCR assays that involve DNA amplification have been developed $(8,9)$. In Iraq, up on our knowledgement, no data are available to identify of Campylobacter spp. from stool and fecal samples using PCR technique. 


\section{Material and methods}

Samples collection

A total of 100 children stool samples were collected who attended to Gynecology and Pediatric Teaching in Diwanyiah governorate. During the period from December 2007 to January 2008.All children patient had clinical sign such as fever, weight loss, diarrhea and bloody diarrhea .The mean of their age of children from 21 day to 2 years from both sexes and different residency.One gram of stool was taken after prepared of peptone water in sterile test tube and putting in test tube containing $3 \mathrm{ml}$ of peptone water in sterile condition then closed the test tube and transported to laboratory during 3-6 hour (10). The healthy children 10 (males and females) were also studied as control as clinical examination showed by clinician specialist, stool samples were taken from each subject.

Isolation and identification of Campylobacter

The digestive samples were high contamination, so this contemn decreasing by culturing on selective media contain antibiotics to prevent the growth bacteria and antifungal to prevent growth of fungi (Trimethprim (5 mg), Vancomycin (10 mg), Nystatine (1 IU), Cephalothin (15 $\mathrm{mg})$ and Ketacanzol (1 mg )) $\backslash \mathrm{L}$ from culture media (11).According to the routine diagnosis procedures recommended by $(12,13,14)$.After culturing samples on Brucella agar and
Columbia agar at $37 \mathrm{C}^{\circ}$ for up to three days in microarophilic condition and samples were centrifuged of $6000 \mathrm{rpm}$ for 15 minutes, then the sediments were collected after discarding the supernatant. The sediments was transferred to eppendrof tube and stored at $-20 \mathrm{C}^{\mathrm{o}}$ if not immediately processed (15).

Solutions and buffers

-Tris acetic acid EDTA buffer (TAE-50 $\mathrm{X})$ and TAE (1X)

This buffer was prepared by according to recommended (16). It was used in electrophoresis.

-DNA Loading dye (bromophenol blue)(16). It was used in electrophoresis.

-Ethidium bromide (0.5\%) (16). It was used in electrophoresis.

-Agarose gel preparation (16).

PCR detection method

I. DNA extraction and purification.

A direct homogenized stool, and colony isolated of Campylobacter spp. were used in DNA extraction protocol as follows; according to manufacturing company instructions((Promega ., USA).

II. Polymerase chain reaction technique (PCR)

The PCR amplification was performed using assay based on repetitive sequence 16s rRNA fragment, the primers Forwared (5-AAT CTT GCG CAA TGG GGG AA$\left.3^{\prime}\right)$ and Revers (5'-GGC CAT CAT GAT GAC TTG AC -3'), (17).

Table (1):Oligonucleotide primer sequences used for PCR amplification of purified DNA of Campylobacter spp. 16S rRNA fragment.

\begin{tabular}{|l|l|l|l|l|}
\hline Primer & Primer sequences & Length & TM* $^{*}$ & TA** $^{* * 1}$ \\
\hline $1 \mathrm{~s}^{1}$ & $\begin{array}{l}\text { Forward (5'-AAT CTT GCG CAA TGG } \\
\text { GGG AA-3') }\end{array}$ & 20 & 60 \\
\hline $1 \mathrm{~s}^{2}$ & $\begin{array}{l}\text { Reverse (5'-GGC CAT CAT GAT GAC } \\
\text { TTG AC -3') }\end{array}$ & 20 & 60 & 55 \\
\hline
\end{tabular}

* Melting temperature

** Annealing temperature 
DNA amplification protocol as follows; according to manufacturing company instructions ( PCR detection kit, Genekam Biotechnology AG. Germany).

\section{Statistical Analysi}

Clinical disease

Most patients were presented with manifestation of Campylobacterosis included diarrhea with or without blood, fever, abdominal pain and body weight loss. The main steps of disease diagnosis were based on the clinical and laboratory diagnosis regarded the last line for the diagnosis of the disease which depends on the clinical signs and symptoms related to Campylobacterosis.

Laboratory diagnosis

Direct examination

The direct examination of stool samples using hanging drop slide revealed the crock screw motility while the Gram's stain prepration showed the G-ve coma shape, small curved and seagull-winged
All results were analyzed statistically by Chi-square $\left(\mathrm{X}^{2}\right)$ test at the level of significant when $\mathrm{P}$-value $<0.01$.The specificity, sensitivity and diagnostic accuracy of the results (18).

\section{Results}

shape. Out of 50 cases of study group (children patients), 20 cases $(40 \%)$ gave positive direct microscopic examination, Figure (1).

Culture method

The colonies of Campylobacter spp. were large or drops dirty watery colonies on Columbia agar and Brucella agar with standard antibiotic concentration rate, In children patients were 9 cases $(18 \%)$ gave positive results. Figure (2).

Biochemical tests

Campylobacter -like colonies on the Columbia agar and Brucella agar plates were subjected to further biochemical tests. The species were identified by performing the following test: Table (2).

Table (2). Identification of Campylobacter isolated from stool of children based on specific biochemical.

\begin{tabular}{|c|c|c|c|}
\hline \multicolumn{2}{|c|}{ Test Campylobacter spp. } & C.coli & C.jejni \\
\hline \multicolumn{2}{|l|}{ Indole } & - & - \\
\hline \multicolumn{2}{|l|}{ Urease } & - & - \\
\hline \multicolumn{2}{|l|}{ Catalase } & + & + \\
\hline \multicolumn{2}{|c|}{$\mathrm{H} 2 \mathrm{~S}$ production on TSI } & $+/-$ & $-/-$ \\
\hline \multicolumn{2}{|c|}{ Hippurat hydrolysis } & - & + \\
\hline \multirow{3}{*}{ Growth } & $42 \mathrm{C}^{\circ}$ & + & + \\
\hline & $1 \%$ glycine & - & - \\
\hline & $3.5 \% \mathrm{Nacl}$ & - & - \\
\hline $\begin{array}{ll}\text { Total } & \text { of } \\
\text { isolation } & \\
\end{array}$ & Childr & 4 & 5 \\
\hline
\end{tabular}




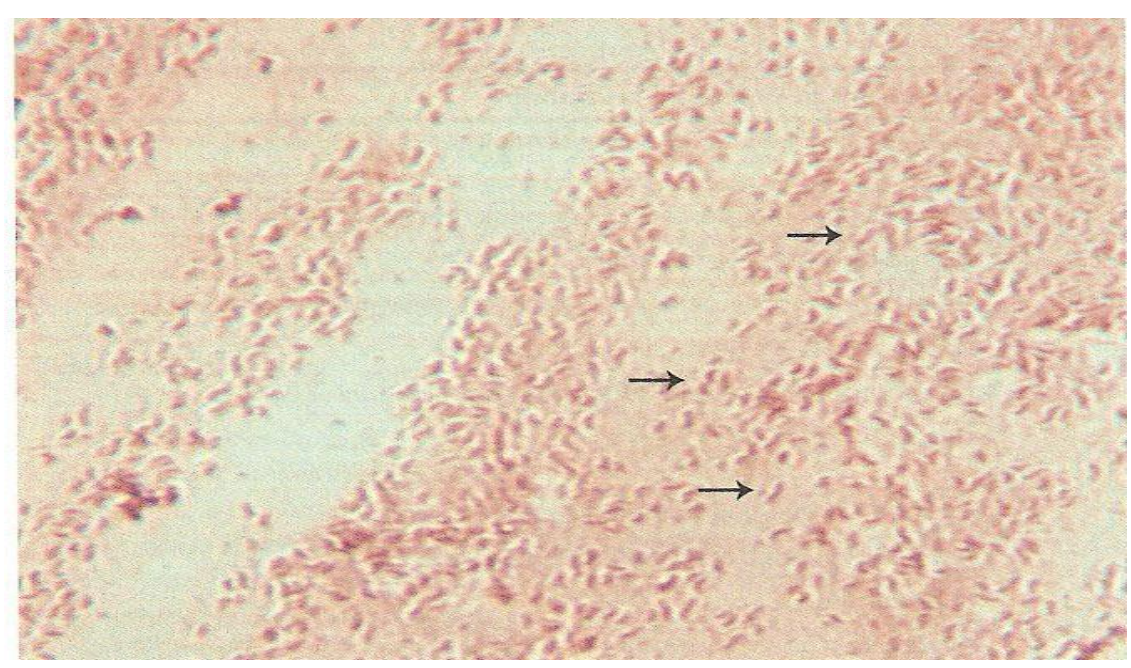

Figure (1). Gram stains appearance of Campylobacter spp. from colony on primary isolation plate. Note seagull and curved forms.

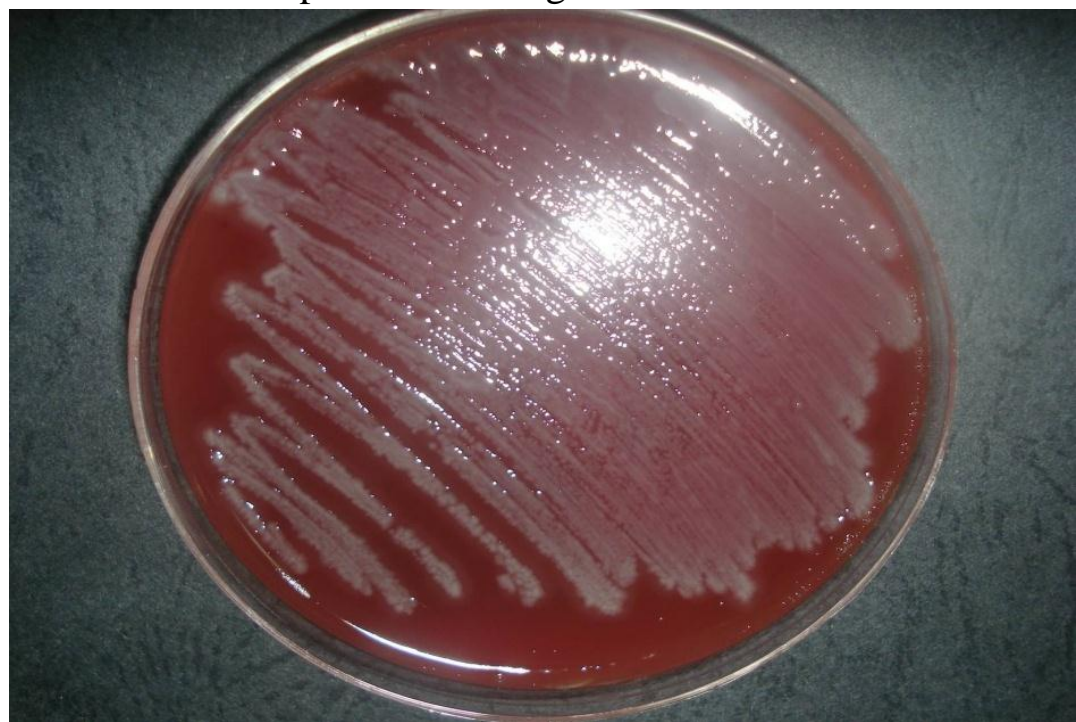

Figure (2).Colonies of Campylobacter spp. growing on Columbia and Brucella agar.

Based on the direct examination, the percent of Campylobacter spp. examination were $(24 \%, 24 / 100)$ of stool samples of infected children, while the

percent of isolation on Columbia agar and Brucella agar were $(9 \%, 9 / 100)$ of stool samples of infected children Table (3).

Table(3). Frequencies of Campylobacter spp. Infection among diarrhea patients using routine test and PCR technique comparison with control group.

\begin{tabular}{|c|c|c|c|c|c|c|c|c|}
\hline & \multicolumn{2}{|c|}{$\begin{array}{l}\text { No. of case } \\
\text { Using D.M.E. }\end{array}$} & \multicolumn{2}{|c|}{$\begin{array}{l}\text { No. of case } \\
\text { Using Culture }\end{array}$} & \multicolumn{4}{|c|}{$\begin{array}{l}\text { No. of case } \\
\text { Using PCR }\end{array}$} \\
\hline \multirow{2}{*}{ Test } & & & & & \multicolumn{2}{|c|}{ Direct } & \multicolumn{2}{|c|}{ Culture } \\
\hline & No. & $\%$ & No. & $\%$ & No. & $\%$ & No. & $\%$ \\
\hline Children & 2 & 40 & 9 & 18 & 8 & 16 & 3 & 33.3 \\
\hline Control grou & 0 & 0 & 0 & 0 & 0 & 0 & 0 & 0 \\
\hline
\end{tabular}




\section{PCR technique}

The DNA of all isolates was extracted and purificated by using genome DNA purification kit. The results were detected by electrophoresis on $1 \%$ agarose gel and exposed to U.V light in which the DNA appear as compact bands (figure3).

The results of PCR amplification which was performed on the DNA extracted from all the studied isolates confirmed by electrophoresis - analysis. By this analysis the strands of DNA which are resulted from the successful binding between specific primers and isolates extracted DNA. These successful binding appear as single band under the U.V light using ethidum bromide as a specific DNA stain. The electrophoresis also used to estimate DNA weight depending on DNA marker (100 bp DNA ladder) and the result of this estimation revealed that the amplified DNA of 816 bp (Figure4).

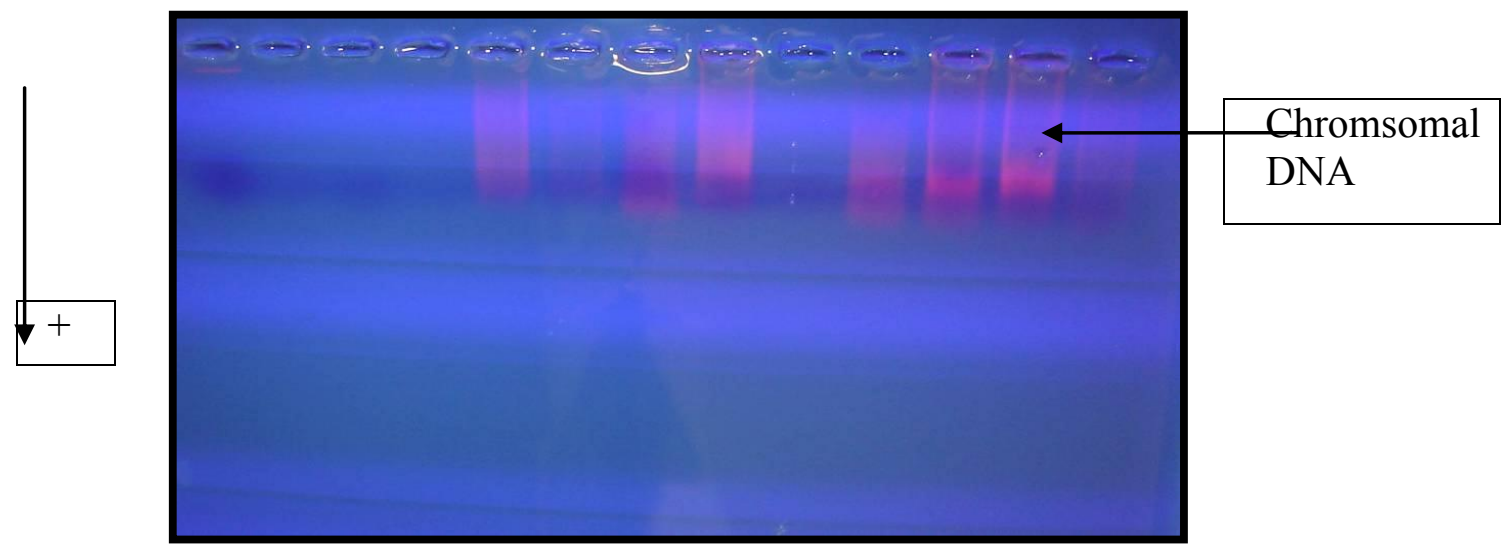

Figure 3: Total genomic DNA extracted from sample using 1\% agarose gel electrophoresis.

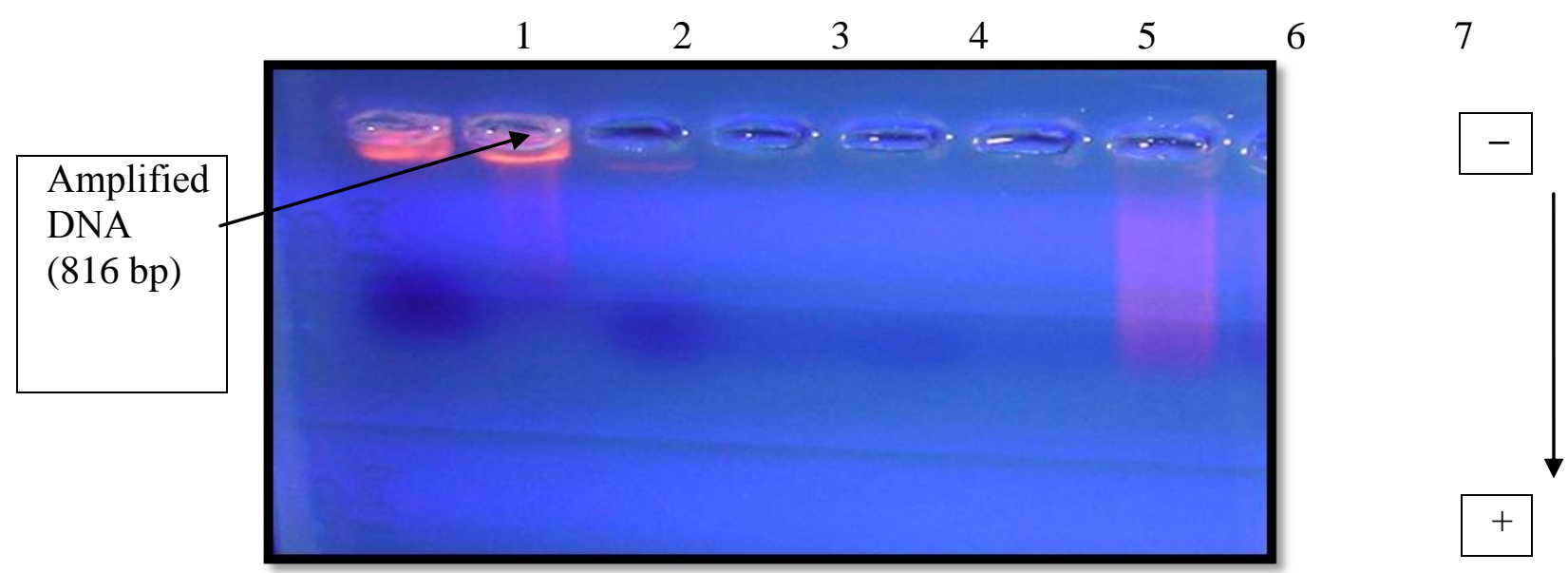

Figure 4: Polymerase chain reaction (PCR) amplification of an $816 \mathrm{bp}$ fragment of $16 \mathrm{~S} r$ RNA. Line 1,2 positive specimens, line 3 positive control, line 4 negative control, line 5,6 negative specimens, line 7, 100 bp ladder. Amplification samples was directly loaded in a $2 \%$ agarose gel containing 0.5 $\mathrm{mg} / \mathrm{ml}$ ethidium bromide with adding loading buffer in electrophoresis.

Relationship between PCR and culture media in children

Out of 9 cases from Campylobacterosis that gave positive on culture media, there were 3 cases $(33.3 \%)$ were positive for PCR detection and 6 cases $(66.7 \%)$ were negative for PCR detection. Out of 41 cases that gave negative in culture media 
detection were $0(0 \%)$ positive PCR detection and 41 cases (100\%) gave negative for PCR detection. There were non-significant differences (P-value
$>0.01$ ) between the PCR and culture media methods in diagnosis Campylobacter spp. Table (4).

Table (4). Relationship results between the PCR method and culture method of

Campylobacter spp. cases .

\begin{tabular}{|c|c|c|c|c|c|c|c|c|}
\hline \multirow{3}{*}{\multicolumn{2}{|c|}{ Tests }} & \multicolumn{4}{|c|}{ PCR method } & \multirow{2}{*}{\multicolumn{2}{|c|}{ Total }} & \multirow{2}{*}{$\begin{array}{l}\mathrm{X}^{2} \text { and } \\
\mathrm{P} \text {-value }\end{array}$} \\
\hline & & \multicolumn{2}{|c|}{ +ve } & \multicolumn{2}{|l|}{-ve } & & & \\
\hline & & No. & $\%$ & No. & $\%$ & No & $\%$ & \\
\hline \multirow{2}{*}{$\begin{array}{l}\text { Culture } \\
\text { method }\end{array}$} & $+\mathrm{ve}$ & 3 & 33.3 & 6 & 66.7 & \multirow{2}{*}{50} & \multirow{2}{*}{100} & $\mathrm{P}>0.01$ \\
\hline & -ve & 0 & 0 & 41 & 100 & & & sigmincant \\
\hline
\end{tabular}

Evaluation of the results of culture media and PCR methods.

Three methods were used for the detection of the etiological agent of Campylobacter spp. in the children stool samples, culture (stool) and PCR detection the study regards the culture method as the gold standard test to other methods.
Culture method versus PCR results in children.

From 3 positive patient confirmed by PCR,3 patient were positive by culture method, so the sensitivity, specificity, PPV, NPV and accuracy rate of PCR were $(33 \%, 100 \%, 100 \%, 87 \%$ and $85 \%)$ respectively. (Table 5).

Table (5).Validity of culture results media Campylobacter spp. confirmed with results of PCR.

\begin{tabular}{|l|c|l|l|l|}
\hline \multicolumn{2}{|c|}{ Test } & \multicolumn{2}{|l|}{ PCR method } & \multirow{2}{*}{ Total } \\
\cline { 3 - 4 } & +ve & -ve & 9 \\
\hline \multirow{3}{*}{$\begin{array}{l}\text { Culture } \\
\text { method }\end{array}$} & +ve & 3 & 6 & 41 \\
\cline { 2 - 5 } & $-\mathrm{ve}$ & 0 & 41 & 50 \\
\hline \multicolumn{2}{|l|}{ Total } & 3 & 47 & \multicolumn{2}{|l}{} \\
\hline
\end{tabular}

PCR method

Sensitivity $=33 \%$

Specificity $=100 \%$

Accuracy rate $=85 \%$

$\mathrm{PPV}=100 \%$

$\mathrm{NPV}=87 \%$

\section{Discussion}

Diarrhea frequent runny or watery bowel moments (poop) is usually brought on by gastrointestinal (GI) infections caused by viruses, bacteria or parasites. The specific germ that cause diarrhea can vary among geographic regions depending on their level of sanitation, economic development, and hygiene (20). In undevelopment countries with poor sanitation or where human waste is used as fertilizer often have out breaks of diarrhea when intestinal bacteria or parasites contamination crops or drinking water, whereas in development countries, 
including the United States, diarrhea out breaks are more after linked to contaminated water (20). In this study, we found that Campylobacter spp. infection in Al- Diwaniyiah Governorate considered one of causes of diarrhea in children have age less than of one years old, Campylobacter bacteria are one of etiologic agent of diarrhea which infect infants and young adults are most commonly affected by these infections, especially during the summer, (21), a source of drink water contamination if untreated, supplies person to person contact in places such as child-care centers, or "food poisoning" (when people get sick from improperly processed or preserved foods contaminated with bacteria) (20).According to the child-care centers or "food poisoning", (children suffering from diarrhea) from 24-48 hour should be examined by direct microscopically detection and culture method because the clinical signs and symptoms of enteritis are not specific to any causes such as bacteria, virus and parasite caused diarrhea. Analysis of Campylobacter spp. is usually performed by direct plating on selective media or by enrichment followed by cultivation on solid selective media (22).Enrichment may be required if the bacteria are present in low numbers or have been damaged by environmental stresses such as temperature changes, nutrient deprivation, dehydration or exposure to atmospheric oxygen, whereas direct culture is recommended for samples in which a high level of Campylobacter is suspected (23).The documented finding is consistent with another study by (24) who found Campylobacter in all age of human but the infection more dangerous in late childhood and the infection top rate in summer season. Consequently, there is a pressing need for a rapid and accessible diagnostic method that could be applied directly on clinical samples in order to identify the many species of Campylobacter isolated in the microbiology laboratory.There was significant relationship between the culture media results and the age of the patients, many are due to the same reasons with direct microscopic examination.A number of unanswered questions regarding the development of molecular technique in the clinical laboratory for the diagnosis of Campylobacterosis have yet to be addressed: (i) which method should be used for extraction of Campylobacter DNA; (ii) which specimens should be tested; (iii) whether Campylobacter specimens should be tested after decontamination; (iv) which criteria for sensitivity, specificity, speed simplicity, and clinical relevance are required; and finally, (v) should a positive internal control always be used with molecular method of this sort, and specifically, should this control be added to the sample, preparation at the very start of the process to determine the efficacy of the sample preparation and amplification procedure (Fermer and Engvel, 1999). The aim of our study was to try to answer several of these questions. The present PCR protocol permitted fast reliable identification of Campylobacter spp. within 4 hour of detection of suspicious colonies on agar plates. Furthermore, the method can also be useful for the rapid detection of Campylobacter in different samples. Specificity, sensitivity and speed of PCR test in diagnosis of Campylobacter shown in this study should encourage the use of this method in routine diagnosis of Campylobacter we compared the performance of various test in different clinical samples for diagnosis of Campylobacter spp. PCR showed the high specificity as compared to other tests and was supported by other studies (26).In this study showed a high PCR specificity in comparison with other testes that used in detection of Campylobacter spp.Various molecular sassy based on polymerase chain reaction (PCR) amplification may provide an alternative to culture methods for the detection of Campylobacter spp. directly in clinical specimens. The finding of Campylobacter 
DNA in stools from a large number of patients with diarrhea suggests that Campylobacter spp. other than C.jejuni and C.coli may account for proportion of cases of acute gastroenteritis in which no etiologic agent is currently identification (27). this study, PCR was used to diagnose Campylobacter spp. by two ways; firstly by diagnosis the Campylobacter spp. microscopically by direct examination, culturing on selective media and biochemical tests, then the results of conventional methods were confirmed with results of PCR technique. These results were compared with second way of diagnosis of Campylobacter (which taken directly from stool cases have Campylobacterosis infection) and diagnosed directly by PCR diagnosis. When results analyzed, we found a high specificity result in PCR method in comparison with direct routine work and PCR. This is agreement with other studies such as (28) and (29). In this study, there

\section{Reference}

1. Stern, N.J. ,(1992). Reservoirs for Campylobacter jejuni and approaches for intervention in poultry. In :Nachamkin , I., Campylobacter jejuni, current status and future trends. American Society for Microbiology, Washington DC,pp ,49-60.

2. Harvey, S.M. and Greenwood, J.R., (1983). Probable Campylobacter fetus subsp. fetus gastroenteritis. J. Clin. Microbiol. 18: 1278-1279.

3. Fennell, C.L.; Rompalo, A.M.; Totten, P.A.; Bruch, K.L.; Flores,B.M. and Stamn, W.E., (1986). Isolation of Campylobacter hyointestinalis from a human. J. Clin. Microbiol. 24:146-148.

4. Goossens,H; Giesendor F.B.A.; Vandawme P.; Viees , L.; Nan den borre, C.; Koeken A.; Quind W.G.; Blomme W.; Hanicq, P.; Koster, D.S; Hofstra H.,Butzler ,J .$P$ and Van den Plas J, (1995).Investigation of an outbreak of Campyloaeter was significant relationship between the direct microscopic test and PCR test in children infection and in broiler but there was no-significant relationship between the culture test and PCR test, presumably in culture test this bacterium very sensitive to environment stress and loss during culturing and gave false results the results agreement with (6).In the present study, the PCR test to isolation of Campylobacter spp. from direct stool samples was had high sensitivity and specificity while used the PCR test to isolation Campylobacter spp. the sensitivity and specificity less then direct, Enrichment may be required if the bacteria are present in low numbers or have been damaged by environmental stresses such as temperature changes, nutrient deprivation, dehydration or exposure to atmospheric oxygen and loss during culture, this results agreement with Fermer and Engvall (25).

upsaliensis in day care centers in Brussels analysis of relationships among isolates by phenotypic and genotypic typing methods. J. Infect. Dis., 172:1298-1305.

5. Blaser M.J and Reller, L.B., (1981). Campylobacter enteritis. N. Engl . J. Med. 305: 1444-1452.

6. Blom K.; Patton, C.M.; Nicholson, M.A. and Swaminathan, B., (1995). Identification of Campylobacter fetus by PCRDNA probe method. J. Clin. Microbial. 33: 1360-1362.

7. Edmonds, P.; Patton, C.M.; Barrett, T.J.; Morris. G.k.; Steigerwalt, A.G and Brenner, D.J., (1991). Biochemical and genetic characteristics of atypical Campylobacter fetus subsp. fetus isolated from humans in the United States. J. Clin. Microbiol. 21: 936-940.

8. Giesenrdeorf, B.A.J and Quint. W.G. V.(1995). Detection and identification of Campylobacter 
spp. using the polymerase chain reaction .Cell. Molec. Biol. 41:625-648.

9. Oliveira, T.C.R.M.; Barbut, S. and Griffiths, M.W., (2005). Detection of Campylobacter jejuni in naturally contaminated chicken skin by melting peak analysis of amplicons in real-time PCR. International Journal of Food Microbiology104:105-111.

10. Agulla, A.; Merion, F. J; Villasante, P.A.; Saza, J. V.; Daz A. and Volasco, A.C., (1987). Evaluation of four enrichment media for isolation of $C$. jejuni. J. Clin. Microbiol., 25: 174 - 175

11. Skirrow, M.B. (1977). Campylobacter enteritis: a "new" disease. British Medicine Journal 2: 9-11.

12. MacFaddin, J. E. (2000). Biochemical tests for identification of medical bacteria 3ed ed. Lippincot Williams and Wilkins, Philadelphia p.214- 289.

13. Cruickshank, R. ;Dngnid ， J.P. ;Marirmion , B.P. and Swain , R.H (1975).Medical Microbiology volume 2. 12th ed., Churchill Living stones London.P.38-39.

14. Collee, J.G.; Fraser, A.G.; Mamion, B.P.; Simmons, A. (1996).Mackie and McCartney, practical medical microbiology $14^{\text {th }}$ ed. Churchill Livingstone, New York.

15. Hoffman, PS; George, H. A; Krieg. NR. and Kmibert . R. M (1979).Studies of the microarophilic nature of Compaylobacter fatus subsp jejuni II.Role of exogenous superoixide anions and hydrogen peroxide. J. Microbiol., 25: 8-15.

16. Sambrook, J.; Fritsh, E.F., and Maniatis, (1989). Molecular cloning, laboratory manual, 2nd ed. Cold Spring Harbor Laboratory.

17. Hernandez, J.; Fayos, A.; Ferrus, M.A. and Owen, R.J. (1995). Random amplified polymorphic DNA fingerprintinof Campylobacter jejuni and $C$. coli isolated from human faeces. Res. Microbiol. 146: 685-696.

18. Niazi, A.D. (2000). Statistical Analysis in medical research. Republic of Iraq. Al- Nehrien University. P.148.

19. Refregier-Petton, J.; Rose, N.; Denij M. A and Salvat, G.(2001). Risk factors for Campylobacter's spp. Contamination in French. Broilerchicken flocks of the end of the rearing period preventive veterinary medicine 50:89-100.

20. Albert, M.J.; Farnque, A.S.G.; Sack, R.B.; and Mahalanabis, D.,(1999).Case-control study of enteropathogens associated with childhood diarrhea in Dhaka, Bangladesh. J. Clin. Microbiol., 37: 3458-346.

21. Obi, C.; Coker. A.; Epoke, J.; and Ndip, R.N. (1997). Enteric bacterial Pathogens in stools of residents of urban and rural regions in Nigeria: a comparison of patients with and without diarrhea and controls without diarrhea. Journal of Diarrhea Disease Research, 15(4): 241-247.

22. Fernandaze, H.; Fagundes Neto, V. and Ogatha, S. (1997). Acute diarrhea associated with Campylobacter jejuni subsp doylei. in Sao Paulo. Brazil. Pediatric Infectious Disease Journal 16: 1098-1099.

23. Negi, SS.; Khan, SFB, Gupta, S.; Pasha S.T.; Khara, S. and Lal S (2005). Comparison of the conventional diagnostic modalities, BACTEC Culture, Indian J. Med. Microbiol , 23: 29-33.

24. Skirrow, M.B. (1994). Diseases due to Campylobacter Helicobacter, and related bacteria. Journal of Comparative Pathology, 111: 11349.

25. Fermer, C. and Engvall, E.O. (1999). Specific PCR identification and differentiation of the thermophilic 
Campylobacter's,Campylobacter jejuni, $C$. coli, $C$. lari and $C$. upsaliensis. Journal of Clinical Microbiology, 37: 3370-3373.

26. Englen, M.D. and Kelley, L.C., (2000). A rapid DNA isolation procedure for the identification of Campylobacter jejuni by the polymerase chain reaction (PCR). Lett. Appl. Microbiol. 31:421426.

27. Giesenrdeorf, B.A.J and Quint. W.G. V.(1995). Detection and identification of Campylobacter spp. using the polymerase chain reaction .Cell. Molec. Biol. 41:625-648.
28. Olsson Engvall, E.; Brandstron, B.; Andersson, L.; Baverud, V.; Trowald- Wigh, G. and England, L. (2003). Isolation and identification of thermophilic Campylobacter species in fecal samples from Swedish chicken. Scandinavian Journal of Infectious Disease 35:713-718.

29. Lund, M.; Wedderkopp, A.; Waino, M.; Nordentoft, S.; Bang,D.D.; Pedersen, $K$. and Madsen, $M$. (2003). Evaluation of PCR for detection of Campylobacter in nations broiler surveillance program in Denmark. Journal of Applied Microbiology 94: 929935.

\section{كثف جرثومة المنحنيات Campylobacter في إسهال الأطفال باستخدام

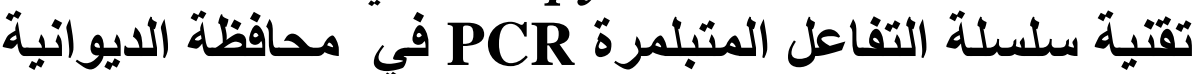

\section{ألخلاصة}

أجريت الدراسة لغرض تثخيص بكتريا . Campylobacter spp. المسببة لحالات الإسهال في الأطفال باستخدام

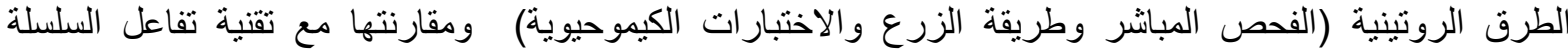

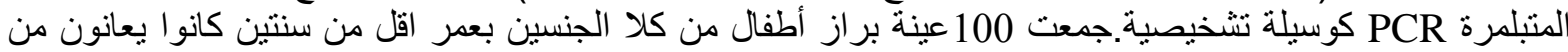

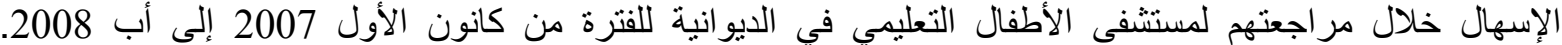

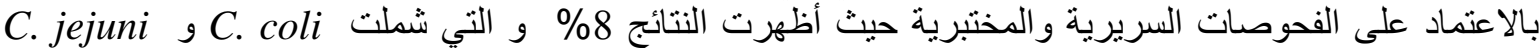
لعينات الاطفال النتائج لم تظهر أبي فروق معنوية (P

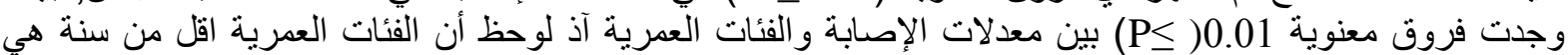

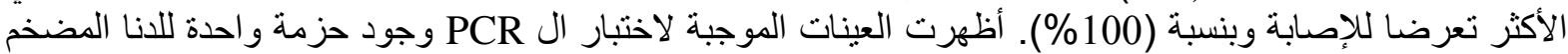

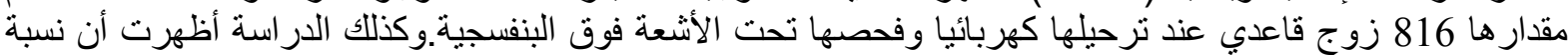

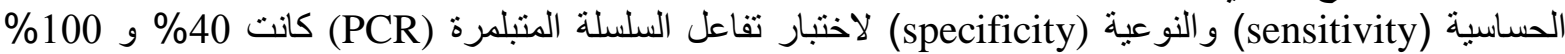

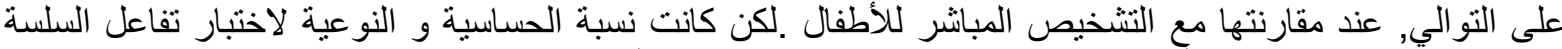

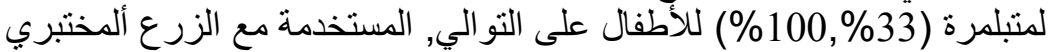

